\title{
Growth and yield response of water melon (Citrullus lanatus var. lanatus) under drip fertigation
}

\section{A. RAJA GOPALA REDDY, D.T. SANTOSH AND K.N. TIWARI}

Received : 21.08.2017; Revised : 09.09.2017; Accepted : 24.09.2017

See end of the Paper for authors' affiliation

Correspondence to :

A. RAJA GOPALA REDDY

Department of Agricultural and Food Engineering, Indian Institute of Technology, KHARAGPUR (W.B.) INDIA Email : rajbckv@gmail.com
ABSTRACT : A field experiment was conducted during 2016-17 at the experimental farm of PFDC, Kharagpur, India to investigate the effect of different levels of fertigation on the water melon growth and yield. The F1 hybrid water melon was planted in a $0.5 \times 0.5 \mathrm{~m}$ spacing and drip irrigated with a row of drippers. Treatment consisted of of 5 levels $(120,100,80,60,40 \%)$ with the Statistical Design Randomized Block with 4 replications. The growth and yield were increased with levels of fertigation at a maximum 32.75 and 29.25 t/ha with 100 and $80 \%$ of fertigation, respectively compared to $40 \%$ of fertigation.

GEY WORDS : Water melon, Drip irrigation, Water soluble fertilizers, Drip fertigation

-HOW TO CITE THIS PAPER : Reddy, A. Raja Gopala, Santosh, D.T. and Tiwari, K.N. (2017). Growth and yield response of water melon (Citrullus lanatus var. lanatus) under drip fertigation. Internat. J. Agric. Engg., 10(2) : 619-622, DOI: 10.15740/HAS/IJAE/10.2/619-622. 